\title{
Working Anita Bryant: \\ the Impact of Christian Antigay Activism \\ on Lesbian and Gay Movement Claims*
}

\author{
Tina Fetner \\ New York University \\ and \\ Cornell College
}

*Earlier versions of this paper were presented at the 1999 Meeting of the American Sociological Association and at the Workshop on Politics, Power and Protest at New York University's Department of Sociology. The paper has benefitted greatly from comments received in each of these sessions. I would like to thank Edwin Amenta, Ellen Benoit, Chris Bonastia, Lane Dunlop, Jeffrey Goodwin, David F. Greenberg, Drew Halfmann, Carrie James, Clarence Lo, Kelly Moore, Guobin Yang, the Eastern Conference All-Stars dissertation group, and anonymous reviewers for detailed comments and valuable insights on earlier drafts. Please direct correspondence to Tina Fetner, Cornell College, Department of Sociology and Anthropology, 600 First Street West, Mount Vernon, Iowa 52314. 


\begin{abstract}
Social movement scholarship claims that opposing movements can create opportunities and generate mobilization for the other side. However, there are still open questions as to how this influence between opposing movements operates on an organizational level. This paper looks closely at one aspect of the impact of opposing movements: rhetorical strategies. I examine historical documents produced by social movement organizations to determine the processes through which interactions between opposing movements are integrated into the everyday work of producing movement claims. This historical analysis evaluates the flyers, newsletters, and press releases of lesbian and gay movement organizations in the United States over time, comparing documents produced before the emergence of the Christian antigay countermovement in 1977, with those produced immediately following the countermovement's entry into the political scene. I analyze the shifts in lesbian and gay activists' claims between these two brief time periods and link these changes to the presence of Christian antigay activists. I find that frames, tone, and language shift for issues that were directly addressed by the Christian antigay movement (lesbian and gay rights), but that no similar change was present for issues on which the antigay movement remained silent (police harassment and lesbian/gay media representations). These findings support the claim that opposing movements alter the political context in which the other side works, but they also demonstrate that new opportunities produced by an opposing movement may be issue-specific rather than movement-wide.
\end{abstract}


"I don't hate the homosexuals! But as a mother, I must protect my children from their evil influence... They want to recruit your children and teach them the virtues of becoming a homosexual."

-- Anita Bryant ${ }^{\mathrm{i}}$

By the middle of the 1970s, a young lesbian and gay movement had made some modest achievements as a result of much hard work. Several cities and counties had added sexual orientation to their lists of non-discrimination statuses. The U.S. Civil Service Commission repealed its ban on homosexual employment in the Federal Civil Service. A number of states had decriminalized lesbian and gay sex by reforming or eliminating sodomy laws (Bernstein 1997; Gay 1978). All of these accomplishments were made in a very difficult political context. Politicians for the most part ignored lesbian and gay constituents. Newspapers, rather than publicizing protests and writing editorials in support of the gay community, made a habit of printing the names and addresses of those arrested in routine police raids of gay bars. Public opinion was hostile to homosexuality (Newport 1999). Despite this opposition, lesbian and gay subcultural communities were forming across the country, and the cultural change captured by the slogan "Gay is Good" was evidenced by annual Gay Pride Parades, lesbian and gay newspapers, magazines and commerce, and lesbian and gay community organizations and events.

Not everyone agreed that coming out of the closets and onto the streets was a good thing, however. Traditionalists opposed the cultural changes that redefined homosexuality as a healthy identity rather than a pathology, as well as the political changes which granted civil rights to gay men and lesbians. In Dade County, Florida in 1977, celebrity spokesperson Anita Bryant formed the first antigay countermovement 
organization in the United States in an attempt to reverse the local discrimination protections that lesbian and gay activists had won. This paper explores the impact that the emergence of the Christian antigay countermovement made on the rhetorical strategies of lesbian and gay activists. Unlike other forms of opposition, countermovement activism turned out to be strategically useful for lesbian and gay activists, even as antigay activists campaigned for the elimination of gay rights.

The political contest of two social movements doing battle against each other has been a rather common sight in recent years. However, what social movement scholarship knows about the impact of one movement on its opposing movement, and vice versa, is still limited (Lo 1982; Meyer and Staggenborg 1996, 1998; Mottl 1980; Zald and Useem 1987). Countermovements introduce a challenge to social movement theory, as they present new obstacles to social movements, and alter the political landscape in which social movements interact. ${ }^{\mathrm{ii}}$ It might seem obvious that countermovements adversely affect the social movements they oppose, as this is their intention. I argue that countermovements can also benefit the movements they oppose through unintended consequences of their actions.

In this paper, I examine one pair of opposing movements in depth, and perform a historical, comparative analysis to determine the changes in claims that the initial movement, the lesbian and gay movement in the United States, undertook in response to the emergence of its countermovement, the Christian antigay movement. ${ }^{\text {iii }}$ This analysis examines the claims of social movement organizations (SMOs) in the lesbian and gay movement before the antigay countermovement had emerged, and compares them with the claims made by lesbian and gay SMOs during the first few years of the Christian 
antigay movement's fight against civil rights for lesbians and gay men. I begin with a discussion of current thinking about opposing movements in the social movements literature and offer a brief description of the histories of the development of these two movements. I then analyze the impact that the emergence of the Christian antigay countermovement made on the political claims of activists in the lesbian and gay movement by examining data in the form of documents produced by lesbian and gay SMOs, including flyers for protests, announcements of sit-ins, newsletters to members, and press releases. I compare the documents produced before the emergence of the Christian antigay movement with those produced after. I track changes in the language, the tone, and the frames used by lesbian and gay organizations over this time, and connect those changes to the antigay movement (for discussions of frame analysis and social movements, see Gamson 1992; Gamson and Meyer 1996; Gerhards and Rucht 1992; Snow, et al. 1986; Snow and Benford 1988; Zald 1996). I find that the emergence of the countermovement impacted the rhetorical strategies used by lesbian and gay activists on lesbian and gay rights, an issue which was contested by the antigay countermovement. However, I find that this shift did not occur in claims made about other political issues that were not directly contested by the countermovement.

\section{The Impact of Opposing Social Movements}

The emergence of a countermovement can impact the political context surrounding contested issues in a number of observable ways. For example, countermovement participants may attempt to create or overturn legislation. They may pressure a corporation, police department, or elected representatives to take a proposed 
course of action. They may engage in cultural crusades to alter values and shared meanings. The collective action of a countermovement is a purposeful attempt to affect the social and political world (see Lo 1982; Mottl 1980; Meyer and Staggenborg 1996) regarding a particular set of grievances. The resulting social, political, and cultural changes can be described as the impact of a countermovement's actions. From this perspective, countermovements are no different from social movements (Lo 1982). Additionally, countermovements will impact the social movements they oppose (Meyer and Staggenborg 1996, 1998; Zald and Useem 1987). The actions, statements, and political presence of a countermovement can alter the political terrain in which social movement actors are accustomed to working. Social movement organizations choose strategies, frame political claims, and develop protest tactics which they believe will be appropriate to the political context, effective for accomplishing their goals, and consistent with their organizational values (Meyer and Staggenborg 1996). Countermovements, by shifting political venues, disputing social movement claims, lobbying politicians, and introducing new frames, alter the political context and create new problems for opposing SMOs.

The social movements literature keeps us alert to a number of important variables that impact the activism of movements and countermovements alike. Organizational analyses point out that resources such as funding, volunteer forces, support from elites, strong organizational infrastructures, and social networks are critical to developing an effective social movement organization (McCarthy and Zald 1977; Freeman 1979; Jenkins 1983; Tilly 1978). Also important in studying the impact of opposing movements are the political contexts in which movements act. Social movement analysts demonstrate 
convincingly that social movement emergence, action, and decline are mediated by political contexts (Amenta, Carruthers and Zylan 1992; Kitschelt 1986; McAdam 1982; Tarrow 1996). Although opposing movements are embedded in the same macropolitical context, political opportunities and local political contexts can differ for two opposing movements. They can shift over time, and one movement can affect the political context of the other (Meyer and Staggenborg 1996).

Existing work provides the necessary groundwork for the study of opposing movements, focusing appropriately on the large-scale effects of countermovement on movement, and vice versa. However, less is written about how countermovements impact the routine work of movement participants, how their efforts to recruit members, raise funds, frame grievances, develop tactical strategies or form collective identities are changed by the introduction of a countermovement opponent. While the intentions of opposing movements are to create barriers to success for their opponents in promoting their conflicting claims, opposing movements can in some ways provide unintended benefits to activists and organizations in the opposing movement as well (Lo 1982; Meyer and Staggenborg 1996; Zald and Useem 1987). This paper examines the one element of the work routine of social movement organizations, the production of political claims. I analyze documents produced in the lesbian and gay movement over an elevenyear period to uncover the impact that the emergence of the antigay countermovement made on the rhetoric used by activists to capture their claims.

My argument, consistent with current scholarship on opposing movements, is that some new benefits are introduced by opposing movement activism, whether those are in the form of new opportunities, increased resources, or strengthened cultural ties and 
collective identities. However, I add that the scope of these new benefits is not indefinite, that indeed the actions and statements by opposing movement actors sets the terms of any response by the other side. To choose to respond is to acknowledge that the issues raised are worth debating and to publicize the actions and claims of the opposing movement. For some social movement organizations, in some contexts, these limits may outweigh the advantages to responding. However, for other organizations, particularly those with limited resources in hostile political climates, the opportunity to respond to opposing movement activists might be the best option.

\section{Case Histories}

The lesbian and gay movement in the United States established its first formal organizations in the 1950s (D'Emilio 1983; Katz 1976). Since then, movement organizations have formed in the name of homophiles, lesbian separatists, queers, and lesbian and gay rights. On occasion, movement organizations have also represented other groups of people who are socially marginalized because of their sexual identities and preferences, including transgender people, bisexuals and the sexual role-play community. These various social movement organizations and their different approaches to social change will in this paper be referred to collectively as the lesbian and gay movement. 
In the late 1960s, the lesbian and gay movement experienced an upsurge in activism, as people involved in the feminist movement and the New Left turned their attention to issues of sexuality. These new, radical gay liberation movement organizations ushered in the "post-Stonewall" era, using militant protest tactics to demand changes in institutions, laws, and social proscriptions against homosexuality (Duberman 1993). These gay liberationists called for "Gay Power" and orchestrated marches, sit-ins, occupations of medical and psychiatric conventions, and "zaps" of politicians who made antigay statements. Some of their activism was cultural, as organizations threw parties where same-sex couples danced together as alternatives to the gay bar scene, a radical gesture at a time when this was an illegal activity and police raids were the norm (Jay 1999; Marotta 1981).

The gay liberation era was a powerful but short-lived moment in lesbian and gay political history, and by the early 1970s, many of the early radical organizations found themselves working alongside reform-oriented activist groups, which advocated for a number of state and institutional changes in the treatment of lesbians and gay men. By the end of 1975, over two dozen cities and counties had adopted gay rights ordinances, legal challenges to state sodomy laws were underway, and homosexuality was removed from the American Psychiatric Association's list of mental disorders (Adam 1987; Cruikshank 1992; D'Emilio 1983; Marotta 1981). The accomplishments of the lesbian and gay movement were substantial, but they still fell far short of the movement's goal of full citizenship for lesbians and gay men. The changes were significant enough, however, to capture the attention of social conservatives who felt that American traditionalism was threatened by activists in the lesbian and gay movement, as well as the women's 
movement, the New Left, and even by apolitical hippies who flouted conventional dress and behavioral norms (Himmelstein 1990). Religious conservatives were well represented among these traditionalists, and Christian evangelicals were at the forefront of a number of social and moral issues, including the antiabortion movement, the antifeminist movement, as well as the antigay movement (Diamond 1998).

Anita Bryant, a small-time celebrity who worked as a spokesperson for a number of corporate interests, learned that Dade County, Florida, where she resided, had adopted legislation that protected people from discrimination based on sexual orientation. She formed the organization, Save Our Children, Inc. in 1977, in an attempt to repeal this bill. Using Florida's initiative process, the group gathered enough signatures to put a repeal measure on the ballot at the next election. At the hands of the county's voters, the gay rights bill was easily overturned (Bryant and Green 1978). Inspired by this initial victory, Bryant decided to take her antigay message on the road and provide start-up funds and information to other people who were interested in repealing the discrimination protections that had been put in place for lesbians and gay men in a number of cities and towns across the country (Bull and Gallagher 1996; Button, Rienzo and Wald 1997). Bryant also inspired California State Senator John Briggs (R-Fullerton) to join her antigay activism. His 1978 California ballot initiative, Proposition 6, would have made homosexuals ineligible for employment in the state's public school system. The Briggs Initiative, as it came to be called, was rejected by the voters, at least in part due to the lesbian and gay activists who mobilized quickly to form a "No on 6" campaign to defeat the measure (Witt and McCorkle 1997).

The Christian antigay movement was organized in a genuine attempt to stop the 
lesbian and gay movement from gaining any more political ground, as well as to repeal some of the legislative gains that had already been won. The countermovement was certainly not trying to provide assistance for the lesbian and gay movement in mobilizing its constituents. Movement leaders did not intend to inspire closeted lesbians and gay men to come out of the closet. And there is no evidence that antigay movement actors were making any attempt to influence the rhetoric of lesbian and gay movement actors, except perhaps to silence them altogether. However, as Meyer and Staggenborg (1996) point out, the development of a countermovement has an impact on the political context in which the social movement is situated. Some of these changes in the political context may turn out to be advantageous to the social movement. These can be interpreted as unintended consequences of purposeful political activism by the countermovement.

Below, I analyze the impact of the emergence of the Christian antigay movement on the lesbian and gay movement's claims, focusing on shifts in language, tone and frames. I claim that while the Christian antigay countermovement may have been successful in undoing some of the policies that the lesbian and gay movement had put into place, its emergence also opened up new rhetorical opportunities for activists working on lesbian and gay rights that had not previously existed. I further claim that these opportunities were not open-ended, but rather were limited by the specific issue that antigay activists chose to contest.

In the lesbian and gay movement in this period, SMOs tended to focus their energy on one of these three issues. Organizations were developed specifically around an issue. For example, in San Francisco, a group of owners of local gay bars created the Tavern Guild to protest vice raids and other police harassment of bar patrons. An early 
national lesbian and gay SMO developed a specialty wing, the Gay Media Action Network, to serve as watchdog of the mass media industry's portrayal of gay men and lesbians. Because different organizations took on different issues, the framing and language of political claims vary according to issue. And it should follow that the mobilization of the Christian antigay countermovement would impact the way that various SMOs make their claims differently depending on the issue at stake as well. The early Christian antigay SMOs focused only on a single issue: lesbian and gay rights. They advocated the repeal of various anti-discrimination ordinances. Though in making their claims, they vilified lesbians and gay men on a number of levels, these early activists were singular in their political goal. Because of this, there was a pronounced shift in the rhetorical strategies of lesbian and gay activists, but only regarding lesbian and gay rights ordinances. The impact of countermovement activism did not spill over into other issue areas. While the presence of countermovement activity may have inspired increased activism on all three of these issues, lesbian and gay activists did not change their rhetorical approach on issues not directly addressed by the countermovement.

\section{Data and Methods}

I collected documentation produced by a number of lesbian and gay movement organizations from 1971 through 1981. The documents are part of the collections of five major lesbian and gay archives in the United States: the Human Sexuality Collection at Cornell University; the Lesbian Herstory Archives in Brooklyn, NY; the Gay, Lesbian, Bisexual and Transgender Historical Society of Northern California in San Francisco, CA; the International Gay Information Center at the New York Public Library; and the 
National Archive of Lesbian and Gay History in New York City. These collections contain records from a number of lesbian and gay SMOs during this period. These documents include announcements, flyers, newsletters, and press releases, which represented these organizations' political claims to a public audience, as well as internal organizational memoranda and personal papers of lesbian and gay activists. The time period compares documents produced from 1971-1976: six years prior to the emergence of the Christian antigay movement, and 1977-1981: five years after its activism began. In searching through files of materials from activist organizations and personal collections of activists, I selected those flyers, newsletters, press releases, open letters and memoranda which contained political claims to include in this analysis. All documents that reported on or advocated some form of action (in other words, made a political claim about something that should change) were included in these data, while other sorts of internal memoranda and organizational briefs were excluded. The documents collected contained claims which clustered around three political issues: 1) lesbian and gay rights, in the form of legal protections from discrimination based on sexual orientation; 2) police harassment of and violence against gay men, lesbians, and transsexuals; and 3) negative representation of lesbians and gay men in film, television and other media. Of the 128 documents I incorporated into my dataset, those concerned with rights far outnumbered the other two issues. I found 99 documents on the issue of rights, 17 on police abuse, and 12 on media. 58 of these documents were dated in the pre-countermovement period (1971-1976), and 70 from the period of countermovement activism (1977-1981). As with any historical analysis, this study is limited by the particularities of the archival collections, which may not be representative of all of the documents produced during this 
period. However, these archives comprise the best collections of primary sources of organized lesbian and gay activism in the United States.

I analyze this data along three dimensions: language, tone, and frame. The language category determines whether the words used to capture the claim are inclusive or exclusive. Documents which use the words "they," "them" or refer to any group as an "other" to be marked as different from the authors and readers are coded as exclusive, or "us/them." Documents which make no reference to a marked other are coded as inclusive, or "we." In a very 1970s style, these documents are often explicit about "coming together" to create change, refer to readers as "brothers and sisters," and so on, making the contrast to the exclusive documents even more marked. To code the frames, I interpret the orienting concepts of the documents by extrapolating the logic of their claims in order to establish the system of meaning to which the claims refer. ${ }^{\text {iv }}$ In advocating a political claim, each of the documents I analyze rests on an assumption that a problem exists which should be corrected. Some documents base their appeals for change on quests for equality and/or justice. I code these into a single "equality/justice" category. I code documents as using a "fairness" frame when their appeals are based on a more general call for fairness rather than justice or equality. Other documents assume or claim that minority populations require protection from hostile aggressors. These documents are coded into a "threatened minority" category. While the language and frames overlap considerably in the data, there is a logical distinction between these two categories. It is feasible that activists could use a "we" language to call for protection for minorities, or an "us/them" language to discuss which groups are or are not enjoying equality. The tone dimension is my attempt to capture the emotional content of these 
documents. My binary categorization scheme is certainly a crude measure of emotional expression, but in this case it is supported by the data, which are quite dramatically bifurcated. In some of the documents, an optimistic, enthusiastic tone is quite evident. Such documents educate the reader about a problem and propose a simple resolution. I code these as having an "educational" tone. Other documents contain information that is intended to inspire outrage in readers. I code these documents as "angry." I did not find any documents that were neutral in tone; I attribute this to the fact that the intent of these documents was to inspire and mobilize readers.

\section{Findings}

The findings I present below demonstrate that the tone, language, and frames of lesbian and gay activists did shift when the Christian antigay movement emerged. There is a striking difference between the rhetoric which was produced by lesbian and gay movement organizations before the emergence of the countermovement and that produced during the years of activism by Anita Bryant and her followers. The findings also demonstrate that this impact was indeed issue-specific. The overwhelming shift in the language, tone, and frames which occurred in political claims about lesbian and gay rights was not present in documents that were concerned with issues of either police harassment or media representation.

\section{Police Harassment}

Flyers announcing protests of police harassment consistently used an angry tone, directly named the specific source of their grievance (either the police officers themselves or the police department in general), and proposed protest actions in the form of marches 
or pickets. Here is an example from a 1975 flyer from Bay Area Gay Liberation (BAGL) from San Francisco:

Mass Gay Picket and Teach in...

Police Captain William O'Connor's policy statement of the SFPD: 'The Police Department feels that homosexuals are unsuited for police work... We feel that they are emotionally unstable.'

Once again, the police have expressed their utter contempt for the tens of thousands of gay citizens of San Francisco. It is nothing new. Just in the past year, the police have shown their anti-gay sentiment in action. Since the illegal mass arrests on Castro Street of a year ago, a wave of heinous murders and brutal beatings have been carried out against gay people. The police have systematically failed to investigate them...

The present policy of the S.F.P.D. is in complete defiance of city law which forbids discrimination based on sexual orientation in all agencies of city government and in businesses contracting with the city (BAGL 1975, emphasis in original).

In this example, BAGL is protesting a policy statement of the police department. They do this by connecting the statement to both the police action in arresting gays and to the police inaction in investigating gay-bashing incidents. They frame their claim as an attack on gays based on their minority status. Their use of emphatic phrases such as "utter contempt," "heinous murder" and "complete defiance" drives the point home that they are angry over this issue.

This angry tone and "us/them" language remains consistent throughout the pre- 
and post-countermovement periods, for claims of police harassment of gays and their lack of concern with antigay violence. The following excerpt is from a flyer produced by New York's Coalition for Lesbian and Gay Rights (CLGR), which describes itself as "a coalition of organizations and individuals formed to fight the attack on human rights led by Anita Bryant and the forces she represents" (CLGR 1977a). In this 1979 flyer, activists draw connections between police brutality and antigay activism:

We Demand Justice!...In San Francisco last night a dozen riot police broke into a gay bar shouting, "Bonzai!" and indiscriminately swinging riot sticks at patrons hiding under tables. The cops yelled, "Get out you goddamned queers," and "Motherfucking faggots, sick cocksuckers!"...We must not forget the repeal of gay rights laws by referendum in Miami, Wichita, Eugene and St. Paul...The attacks on us throughout the country are escalating at an alarming rate...On October 14, 1979 all of us from New York, San Francisco, Los Angeles, Chicago -- everywhere -- will march on Washington, DC for lesbian and gay rights...We must unite to stop them! (CLGR 1979).

The tone of this flyer is angry, and the inclusion of the police officers' profanity is an attempt to inspire the reader to be offended and enraged, consistent with the use of anger before the countermovement emerged. There is an urgency in the claim that attacks against gays are increasing "at an alarming rate." In this later flyer, the police brutality issue is juxtaposed against the activism of Christian antigay movement, and the proposed response is to join the fight for gay rights legislation via the national March on 
Washington. In these documents, there is no shift in the language or tone of the documents on the issue of police harassment, nor in the frame which captures gay men and lesbians as a threatened minority targeted by police. However, the Christian antigay movement is tacked on as an additional source of attack, equated with the police brutality, and fighting for gay rights is seen as the appropriate solution for both of these problems.

\section{Gay and Lesbian Representation in Media}

When the issue turns to media representations of lesbians and gay men, there is a similar consistency between items produced both before and after the emergence of the Christian antigay movement. Below is an excerpt from a 1975 newsletter produced by National Gay Task Force (NGTF — now known as the National Gay and Lesbian Task Force, or NGLTF), which reviews a protest against NBC for airing representations of lesbian girls as reform-school rapists in the following flyer:

The Gay Media Alert Network is alive--and kicking. Upon learning in advance that the lesbian television film Born Innocent was to be rebroadcast on October 25, NGTF sent out letters to participating GMAN organizations around the country notifying them of the re-run and suggesting ways to pressure and protest. NBC affiliates were the target of numerous sit-ins and protests. Happily, eight local stations canceled the program....and four sponsors withdrew (NGTF 1975).

While the conclusion that eight cancellations is a happy result of a nationwide protest may be questionable, it is clear that the tone of this blurb is informative and positive, in contrast to the angry tone used in documents protesting police harassment. The message 
focuses more on the protest work than on the source of the grievance, leaving the decision-making process by NBC in the background, rather than vilifying network executives. This conveys a message that positive social change is happening, where police brutality flyers point to ongoing oppression and a lack of progress.

The emergence of the Christian antigay movement does not impact the tone or language of these documents, as this upbeat sentiment is also found in all of the documents created in the post-countermovement time period. The following press release, which was produced in 1977, incorporates news of the countermovement into its introduction of a pro-gay media campaign; however, the flyer's tone is still educational and the language used is inclusive, as evidenced by its repeated usage of "we:" We have examined the reasons for the defeat for human rights in Dade County, Florida, and have reached the following conclusion: the majority of voters did not understand the discrimination gay people actually experience,...their votes were based on emotional attitudes toward lesbians and gay men and their views on the status of homosexuality in society...To this end, we announce our immediate plans to embark on a nationwide education project, the "We Are Your Children" Campaign for Human Rights. We will show the American public who we really are, and that we are not afraid of the truth...(NGTF 1977a).

Like the earlier announcement, the tone of this press release is pleasant, and its purpose is to inform rather than to enrage. It is non-combative, even though this campaign to improve the image of homosexuals in the eye of the American public was a response to the antigay countermovement. Like the protest against NBC, the message here is that 
antigay sentiment is simply a misunderstanding, matter of not having the correct information about lesbians and gays. Its uses a fairness frame, and it implies that the problem of antigay action just requires a small correction in an otherwise reasonable political world. The introduction of the countermovement action did not disrupt this perspective for lesbian and gay activists, and the antigay activism did not promote a major shift in rhetoric around the issue of lesbian and gay media representation.

\section{Lesbian and Gay Rights}

When the issues presented in the documents turn to lesbian and gay rights, however, there is a distinct shift in the way lesbian and gay SMOs' claims are presented after the emergence of the antigay countermovement. In the period before Bryant's group formed, appeals for gay rights emphasize similarities between homosexuals and heterosexuals, make appeals based on justice and equality, and construct parallels to the civil rights movement. After the countermovement became active, documents produced by lesbian and gay SMOs invoke outrage and speak of lesbians and gay men in the role of victim. This frame, which captures lesbians and gay men as a threatened minority, is supported by a new "us/them" language, which diverges from an earlier emphasis of similarities to other groups. And finally, documents become much more specific when referring to opponents, moving away from references to "society," "government" and "employers," to Anita Bryant, John Briggs, and the constituencies they represent as the locus of gay oppression.

To discuss these changes in claims pertaining to lesbian and gay rights in detail, I select several documents from New York City-based lesbian and gay SMOs. For the 
duration of the period under review, a city-wide gay rights bill was repeatedly being reviewed by the city council. The bill prohibited discrimination against lesbians and gay men in the areas of housing, employment and public accommodations. It was introduced in 1971 because of a petition drive by several lesbian and gay organizations, and was either delayed in committee or voted down each year, until a version of the bill was finally passed in 1986. During the time period covered by this research, the NYC Gay Rights Bill was a constant; it was continually being considered by the Council, and it consistently failed to get out of committee or to secure the necessary number of votes for passage. This bill provides a good window through which to view the ongoing activism of several lesbian and gay SMOs before, during, and after the emergence of the Anita Bryant-led countermovement in Florida, a battle which had no direct impact on gay and lesbian life in New York, but which had tremendous symbolic value for activists.

The organizations involved in this activism included the Gay Activists' Alliance, the Coalition for Lesbian and Gay Rights New York, Lesbian Feminist Liberation, and the National Gay Task Force. The Gay Activists' Alliance (GAA) was a New York-based social movement organization with several hundred members, which considered itself the leading lesbian and gay SMO in the city. Some of the issues the GAA stood behind were the repeal of New York State's sodomy law, ending police brutality toward gay men, and stopping negative representation of homosexuals in film and television. GAA takes credit for putting the first proposal for a gay rights bill, Intro 475, before the New York City Council in 1971, by pressuring council members to introduce the legislation. Their repeated calls for public support for the bill made claims around the potential for landlords or employers to discriminate against gays, but did not use specific examples of 
antigay discrimination in which to ground their claims. A typical example of GAA gay rights rhetoric prior to the formation of the Christian antigay movement reads like the following 1971 flyer for a petition drive to support Intro 475 :

If you're gay you have no civil rights protection...Y You cannot be hired. You can be fired because you are gay or because an employer thinks you are gay...You can not rent an apartment. You can not buy property. You can lose the apartment you have because you are gay or because the landlord thinks you are gay...You can be refused service at a bar, restaurant, café, nightclub, or hotel because you are gay, or because the proprietor thinks you are gay. "Intro $475 "$...guarantees to gay people the same civil rights that are guaranteed to other minorities. (GAA 1971)

The claims in this flyer emphasize the similarity between gay people as an oppressed group, and other minorities who experience discrimination. The claims appeal to a sense of justice, and imply that this bill will be the one adjustment required to fix an otherwise fair and equal civil society. The message is that civil rights are guaranteed to everyone else besides gays (and therefore no discrimination occurs), and this bill is the missing link in an otherwise strong social chain. There is also an appeal for heterosexual support for the bill embedded in the repeated phrase, "if you are gay, or if [someone] thinks you are gay" (GAA 1971), which makes the case that homosexual rights issues also extend to heterosexual people.

The educational approach of the flyer implies that GAA believed that not all gays were aware that they could be legally discriminated against. They must have felt that issues of discrimination were either too rare to capture the notice of the gay community, 
or that they were hidden from general view. However, they did not supplement their educational efforts with stories of actual discrimination in these or other flyers obtained during this time period. In fact, another flyer published by the GAA called for people experiencing discrimination to come forward and tell their stories:

\section{FIGHT ANTI-GAY EMPLOYMENT PRACTICES IN NEW YORK}

\section{CITY!}

If you were denied a job--if you ever lost a job--if you were ever harassed in your job because of your being gay--we need your help!!

The Fair Employment Committee of the Gay Activists Alliance needs information and testimony regarding anti-gay employers to present to the City Commission On Human Rights public hearing in late October. (GAA 1972a)

Note that this data collection was to be used to appeal to officials in the city. Nothing was found from the group in which these stories were included in future political calls for action. This discursive strategy left the discriminators unnamed, and left the activists to refer to only vague generalities, such as landlords, employers and proprietors, as the potential source of antigay oppression. This strategy is different from GAA's approach to other issues, such as protests of the beatings of gay men, in which the names of specific individuals or police precincts are identified publicly.

In another example, a 1972 flyer on the NYC civil rights bill is explicit in its optimism about the transformative potential of anti-discrimination legislation:

The bill will guarantee the right of New York's 800,000 homosexuals (gay people) to earn a living, live in decent housing and to live life free of 
political and economic harassment...The bill will help ensure the right of

all New Yorkers to the privacy of their own bedrooms... (GAA 1972b).

In addition to being educational and upbeat, this flyer relies on a justice frame, in which the passage of this local bill is the key to justice for all gay people, perhaps to an unrealistic degree. Despite the professed power of this yet unpassed legislation, however, there is a distinct absence of any outrage in the tone of this flyer.

This changed dramatically with the emergence of Anita Bryant's antigay countermovement actions in Dade County, Florida. Although Bryant's successful repeal was local to the Miami area, her notoriety and the issue's salience with the press gave Christian antigay efforts national attention. The lesbian and gay movement in New York City could have either been intimidated by the countermovement efforts, or ignored them altogether. Rather than choose these reactions, a number of social movement organizations decided that this moment was an opportunity to make significant advances in lesbian and gay rights, and stepped up their activism significantly, including forming the umbrella Coalition for Lesbian and Gay Rights (CLGR). This group, on behalf of GAA and a variety of other New York lesbian and gay activist groups, integrated countermovement activity and rhetoric directly into its claims for passage of the gay rights bill. This 1978 flyer invokes the specter of Bryant's repeal campaign to make the case that the gay rights bill should be passed:

For seven years, the lesbian and gay community of New York City has been fighting for passage of a bill in the City Council that would ban discrimination against us in jobs, housing, and public accommodations...Things are different this time around... similar 
legislation has now been passed in some 40 cities. But the wider opponents of lesbian and gay rights are also better organized--and on a much wider scale. They have already succeeded in reversing such legislation in Miami (June 1977) and in St. Paul (April 1978)...These referenda represent only the beginning of a full-scale assault on the hardwon gains of lesbians and gay men...They must be stopped now! (CLGR 1978)

There are many practical reasons why the lesbian and gay rights movement would change from a strategy of general claims about civility and justice, to one of referencing the countermovement as a threat to the lesbian and gay community. The countermovement grounds the claims of the lesbian and gay movement in a tangible location. Rather than referring to a potential to discriminate, the countermovement points to people and rhetoric which actively attack gay rights. Furthermore, the presence of the countermovement increases the sense of urgency of movement claims. Where the passage of a gay rights bill at one time may have seemed like an inevitability, pointing to Christian antigay activism makes it clear to the lesbian and gay movement's audience that gay rights is a highly contested issue. The message is that in order to secure lasting rights, a major effort will be required.

Internal memoranda within the lesbian and gay movement indicate that this shift is not simply coincidental to the emergence of the countermovement. Rather, statements within lesbian and gay SMOs indicate that this was a strategic response to new political conditions which activists attributed to the countermovement. The NGTF issued several directives to member organizations, indicating that this SMO embraced the emergence of 
the antigay countermovement as a welcome display of antigay sentiment, which it was trying to prove existed to the American public all along. Here is a quote from a memorandum on the topic that was distributed to lesbian and gay SMOs around the country:

NGTF leaders advise that we should exploit the publicity value of Bryant's campaign against gay rights in order to explain the issues involved to the widest possible number of people. Bryant is really the perfect opponent. Her national prominence...insures national news coverage...while the feebleness of her arguments and the embarrassing backwardness of her stance both makes her attacks easier to counteract and tends to generate "liberal" backlash in our favor. Her "Save Our Children" campaign vividly demonstrates just why gay rights laws are needed--in order to protect our people against the sort of ignorant, irrational, unjustifiable prejudice typified by Anita Bryant. (NGTF 1977b)

This reaction to Bryant's campaign is surprising, considering that for the first several months of its existence, the new countermovement was successful in every city in which it ran a gay rights repeal campaign. The above quote is not evidence of a stunned social movement, desperately trying to salvage some good out of a sinking ship, but rather a confident movement ready to use the increased news coverage that Bryant will attract to its advantage.

The NGTF readied the lesbian and gay organizations of the country to respond to every news story of the Save Our Children ${ }^{v}$ campaign, in order to take advantage of the new opportunity for public voice. Even when news stories did not include a statement by 
someone in the lesbian and gay movement in its coverage of Anita Bryant, their attention to the rights repeal campaign created opportunities for lesbian and gay SMOs to write letters to the editor and demand air time for rebuttals of Bryant's claims. And while the movement was tailoring its tactical strategy to countermovement-created opportunities, it was also constructing a new rhetorical strategy around the threat of all the malicious Anita Bryants around the world who want to deny civil rights to lesbians and to gay men. Movement organizations constructed Bryant's image as the epitome of ignorance and hate, the perfect example of the kind of ill will that gay men and lesbians have to deal with in their everyday lives. Bryant served as the representation of lesbian and gay oppression in the new rhetoric of the lesbian and gay movement. This was a purposeful, strategic choice by national organizations such as the NGTF, who advised lesbian and gay SMOs to use Bryant as a stepping stone to their claims:

Ms. Bryant... has given us visibility and public exposure in the media to make our case. We are constantly challenged by legislators and others to document discrimination against gays; she is a magnificent example of just that! (NGTF 1977c)

Bryant became the poster child of intolerance for the lesbian and gay movement, as did State Senator John Briggs, upon the introduction of his California initiative banning lesbians and gay men in public schools, Proposition 6. This flyer was created by the Bay Area Coalition Against the Briggs Initiative (BACABI), which formed in response to Proposition 6:

A collection of conservative groups--commonly called the "New Right"-are attempting to channel the anger and frustration millions of Americans 
are feeling about high taxes, unemployment, housing costs, the crisis within the family and the deterioration of the school system into attacks on the rights of minorities, women, public employees, the labor movement and gay people. This kind of scapegoating is similar to what took place in Nazi Germany... (BACABI 1978)

This equation of antigay activists with Nazis is not limited to the fight in California. In New York, former GAA president David Thorstad penned the following in a press release promoting cooperation between lesbian and gay SMOs:

Our opponents are taking a page from the annals of Nazism. The Nazis first developed a final solution to the homosexuals of Germany in 1934, and then extended it to the Jews, the leftists, and other social "undesirables." Nazi morality was based on the same kind of Christian "virtue" that Anita Bryant and her Nixonian cohort are using against us... (Thorstad 1977)

There were many connections drawn between lesbian and gay movement battles in Florida, California and New York City. Note below how these antigay actions, so distant from New York in terms of the impact they will have on lesbian and gay residents, are incorporated into CLGR's call for a New York City gay rights bill:

Picket at City Hall for NYC Gay Rights Bill Intro 384

Passage of Intro 384 is essential to halting the nationwide wave of anti-gay bigotry as is the defeat of Proposition 6 (the Briggs Initiative) which would mandate discrimination against lesbian and gay school employees 
and their supporters. If this proposition wins on Nov. 4 it would set a nationwide precedent and have a tremendous effect on the passage of our bill in NYC. (CLGR 1977b)

The use of the California initiative to inspire activism in for a local New York gay rights bill exposes lesbian and gay SMOs' belief that the anger which antigay activists like Bryant and Briggs stir up will be a strong motivation for lesbians and gay men to join gay rights actions. CLGR claims that passage of the gay rights bill in New York City will have a symbolic impact in the national fight against antigay activism. Of course, this bill was not passed that year. The lesbian and gay activists were fighting against the inertia of a city council unmotivated to take on an unpopular gay rights bill, not the outspoken activists of the Christian antigay movement. Regardless, Briggs and Bryant were the banners flown to attract lesbian and gay supporters to rallies for the bill.

\section{Table 1 about here.}

Table 1 summarizes the presence of absence of shifts in the language, tone, and frames of claims made by lesbian and gay activists on these three issues over the period under review. For rights-based claims, shifts in tone, language, and frames are evident in almost all of the documents collected. Although a few documents in the precountermovement period use an angry tone, for the most part, rights-based documents in the early period have a positive, educational tone, informing readers about the status of various local bills and the collective action planned to pressure legislators into passing these bills. Given this choice of tone, it is not surprising that early rights-based documents used an inclusive "we" language which points out the protest events, meetings, and social gatherings where a reader could go to join others in collective 
action, as opposed to a more divisive "us/them" language, which distinguishes social movement participants from an external oppressor. Claims are expressed using both a justice frame, which promote rights legislation as the way to prevent unjust discrimination, and/or an equality frame, which captures anti-discrimination protection as the path to equality. After the emergence of the countermovement, these aspects of the political claims shift dramatically. In the later period, the tone of the documents is overwhelmingly angry. Although there are still educational components to some of the documents, these largely focus on telling readers why they should be outraged. Invoking the activism of Christian antigay organizations, the documents shift away from using a more inclusive "we" language to one that distinguishes between "us," a lesbian and gay audience of readers, and "them," the Christian antigay activists who embody the threat to lesbian and gay rights. In this shift, the documents invoke a threatened minority frame, which calls for rights legislation as a protection from a hostile aggressor.

Documents that contain claims about police harassment or media representations of lesbians and gay men do not exhibit the shifts that are evident in the rights-based claims. Consistently educational and upbeat in tone, documents on activism regarding media representation use an inclusive, "we" language even when calling for collective action. These calls to action ask readers to contact local television or radio stations, and suggest a polite and friendly form of protest. Documents use a justice frame to discuss media representation, decrying the disparity between media representations of lesbians and gay men as unhealthy, unhappy, criminal, or mentally ill, and the reality of the lesbian and gay population as normal, healthy and diverse. This tenor is present in all of the documents collected that focus on media representations throughout this time period. 
The tone, language, and frames of documents on the topic of police harassment starkly contrast those of the media-related documents. The brutality and disrespect of police actions prompted an angry tone in these documents, and a very clear "us/them" language, in which "them" referred to the police. In all of the police harassment documents, activists represent gay men in particular, and sometimes lesbians, as a threatened minority subject to attack by police. Although documents in the post-countermovement time period connect Christian antigay activism to police harassment experienced at the local level, the tone, language, and frames of these documents do not shift for this issue.

\section{Conclusion}

These findings demonstrate that movements do impact the choices and constraints of activists in an opposing social movement camp. Lesbian and gay movement actors responded to the emergence of the Christian antigay movement by altering the tone, language, and frames they used in making political claims to the state. Though the evidence presented here shows that activists were aware of the new problems that the Christian antigay movement presented to their causes, they also reveal that activists were aware of, and willing to take advantage of, new opportunities for activism. This is not to say that gay and lesbian activists did not face opposition prior to the emergence of an organized antigay countermovement. Indeed, police raids on gay bars and cruising strips were routine, and elected representatives often refused to meet with activists or acknowledge their demands (Marotta 1981). The new form of opposition that the Christian antigay countermovement mounted intended to block advances in civil rights for lesbians and gay men. These countermovement activists chose the social movement 
organizational form to reverse some of the progress made by lesbian and gay movement organizations, and on several counts, they were successful. Bryant's repeal of the Dade County gay rights ordinance, and those in a string of cities across the country, are one measure. Another measure is the explicit contest over the validity of lesbian and gay activists' "Gay is Good" motto, which Christian antigay movement directly attacked, providing a cultural opponent to the lesbian and gay movement as well as a political one.

As this new countermovement opponent set about undoing the work of the lesbian and gay movement, lesbian and gay activists saw several potential advantages that did not exist prior to this point. They had been struggling against invisibility and against political insiders who did not believe that discrimination against them was a serious matter. Outside the public sphere, many activists directed their protest toward breaking into the view of heterosexist media so that the injustices against lesbian and gay people could be documented. Similarly, many activists attempted to create a voice that would be heard by elected representatives so that unjust laws could be changed. Doing so, however, required activists to seek public exposure and to accept the accompanying risks of job loss, family rejection and public harassment. Christian antigay movement activists successfully drew the debate about gay rights into the public sphere at a point when the lesbian and gay movement could not. Lesbian and gay movement activists who had been fighting against invisibility saw this public debate as a new opportunity for pro-gay publicity and an occasion to encourage increased mobilization.

Several lesbian and gay activists saw in the new leaders of the Christian antigay movement an opportunity to personify the homophobic sentiment of the nation and to demonstrate their grievances in a tangible, coherent way. Activists in rights-oriented 
lesbian and gay SMOs strategized to respond to the Christian antigay activism. Lesbian and gay activists changed the language, tone, and frames of their appeals, owing to the new rhetorical opportunities created by a tangible opponent with strong symbolic value. Rhetorical strategies used to make claims moved from general calls for justice to a specific naming of the threat to lesbian and gay rights, and an image of that threat embodied in Anita Bryant. The countermovement served as evidence that intolerance toward gays was a serious social problem, lending credence to lesbian and gay activists' claims that rights ordinances were necessary. In addition to pointing fingers at the antigay movement, however, lesbian and gay SMOs shifted from frames of justice and equality to frames that portrayed lesbians and gay men as a threatened minority, and began using language that divided the world into "us" and "them" as opposed to demanding inclusion in civil society.

The data further demonstrate that this "us/them" language was even adopted by SMOs that were not directly engaged with opposing movement organizations. The symbolic impact of the Christian antigay movement was sufficient motivation for lesbian and gay organizations in cities such as New York, where no formal antigay activism had developed, to make organizational as well as discursive shifts which acknowledged both the threat that the countermovement's emergence embodied and the opportunities that the countermovement introduced. This suggests that the impact of opposing movement activism may be stretched beyond organizational and geographic boundaries. Activists in far-flung opposing movement organizations can respond to activism by their opponent, and can and do make the same sorts of strategic shifts that are made by actors in SMOs which are directly affected by opponents' activism. 
However, I argue that the new opportunities created by the emergence of a countermovement are not unlimited; rather, they are restricted by the choices and actions of countermovement activists. In this case, the disputed political issue of the countermovement, anti-discrimination legislation, is the only one for which lesbian and gay activists shifted their rhetorical strategies. On other issues, strategies remained consistent throughout the pre-countermovement and post-countermovement time frames. The impact that the actions of Christian antigay activists made on the lesbian and gay movement's rhetorical strategies did not extend beyond the issue of lesbian and gay rights in the form of anti-discrimination legislation. Lesbian and gay activists did not change the tone, language, or frames of their claims pertaining to the issues of police harassment or media representations of lesbians and gay men, issues that were not addressed by countermovement activists. This finding illuminates the bounded nature of new opportunities created by opposing movements. Even though lesbian and gay activists were willing to incorporate bits of information about the activities of the Christian antigay movement into their claims about issues other than civil rights legislation, they did not significantly change the way they framed those claims or the language they used to express themselves.

This analysis, by examining historically the public actions of social movement organizations, provides new insights into the dynamics of opposing movements. In these distinctive political and cultural battles, the actions of one movement can impact the political contexts and resources of the other side. The findings in this paper demonstrate that this impact is mediated by social movement organizations, which determine the nature and content of their responses. These responses are actions in their own right, and 
surely impact the countermovement in a similar way. Although it is true enough that, over time, this action and reaction between movement and countermovement comprise the "loosely coupled conflict" (Zald and Useem 1987) of long-term opposing movement, this paper moves beyond this abstract view to examine the specific claims of social movement organizations. This approach is a significant step for the social movements literature in turning its insights about the relationship of opposing movements into a more specific conceptualization of activists' decision-making processes. 
iQuoted from a direct mail fundraising letter from Bryant's organization, Anita Bryant Ministries. The letter is undated; this organization existed from 1977-79. Emphases in original. Letter preserved by the National Gay, Lesbian, Bisexual and Transgender Historical Society of Northern California.

${ }^{\text {ii } A ~ n o t e ~ o n ~ t e r m i n o l o g y: ~ O p p o s i n g ~ m o v e m e n t s ~ a r e ~ t w o ~ s o c i a l ~ m o v e m e n t s ~ t h a t ~ w o r k ~ o n ~ t h e ~ s a m e ~ s e t ~ o f ~}$ issues, but toward opposite ends. I use the terms social movement and countermovement to capture this relationship at its earliest stage. Countermovements are distinguished from other types of social movements in that they enter the political scene in response to another social movement. Therefore, I find it helpful to use the term countermovement when discussing the moment of its emergence to distinguish it from the social movement to which it is opposed. After this initial point, I use the term opposing movements to demonstrate that social movements and countermovements each respond to the other's actions in similar ways; the order in which they emerged is no longer relevant.

iiiThe term Christian antigay movement refers to the specifically anti-homosexual activism of conservative Christians. Christian identity and ideology are central to this movement, and so I use this term to distinguish this activism from other antigay activism. In the early days of this movement, activists formed organizations which were wholly dedicated to issues of homosexuality. Later, antigay activism was folded into multi-issue, "pro-family" organizations. I use this term to capture the movement throughout its history.

${ }^{\text {iv }}$ See Gerhards and Rucht (1992) for an analysis of the frames used in movement-produced leaflets. By identifying the structure of argumentation of the claims, they interpret the meaning system, or frames, on which the logic of the claims rests.

vDue to a dispute with a child-assistance agency from Connecticut, Save Our Children changed its name to Protect America's Children in 1977 (Bryant and Green 1978). 